\title{
SYNTHESIS, SPECTRAL CHARACTERIZATION AND ELECTROCHEMISTRY OF VANADIUM(V) COMPLEX WITH TRYPTOPHAN
}

\author{
SEMIHA ÇAKIR ${ }^{*, 1}$ and ENDER BICCEER ${ }^{2}$ \\ ${ }^{I}$ Department of Chemistry, Faculty of Arts and Sciences, Gazi University, 06500 Teknikokullar-Ankara, Turkey \\ ${ }^{2}$ Department of Chemistry, Faculty of Arts and Sciences, Ondokuz Mayls University, 55139 Kurupelit-Samsun, Turkey
}

(Received: September 14, 2009 - Accepted: February 2, 2010)

\begin{abstract}
A new oxovanadium $(\mathrm{V})$ complex of $\mathrm{NH}_{4} \mathrm{VO}_{3}$ and tryptophan $(\mathrm{TrpH})$ has been synthesized in aqueous solution at pH 6.0 and characterized by elemental analysis, UV-Vis, FT-IR, ${ }^{1} \mathrm{H}-\mathrm{NMR}$ and mass spectroscopic data. The complex $\left(\mathrm{Na}_{4}\left[\mathrm{~V}_{3} \mathrm{O}_{9}(\mathrm{Trp})\right]\right)$ was diamagnetic in nature as was evident from the electron spin resonance spectroscopy (ESR) and the magnetic susceptibility measurements, in conformity with the presence of vanadium(V) in the structure. The electrochemical behaviour of $\mathrm{Na}_{4}\left[\mathrm{~V}_{3} \mathrm{O}_{9}(\mathrm{Trp})\right]$ complex was also studied on the hanging mercury drop electrode (HMDE) by using cyclic voltammetry (CV). The cyclic voltammograms of $\mathrm{Na}_{4}\left[\mathrm{~V}_{3} \mathrm{O}_{9}\right.$ (Trp) ] complex exhibit two new reduction waves at $-0.38 \mathrm{~V}$ and $-1.01 \mathrm{~V}$ in Britton-Robinson buffer ( $\mathrm{pH} 6.0$ ) for the potential range from $0.0 \mathrm{~V}$ to $-1.2 \mathrm{~V}$.
\end{abstract}

Key words: Vanadium complexes, Tryptophan, Spectroscopy, Voltammetry.

\section{INTRODUCTION}

Tryptophan (TrpH, Scheme 1) is well known as one kind of essential amino acids in human and herbivores bodies, and the precursors of catecholamine synthesis such as dopamine and serotoni ${ }^{1,2}$. The brain serotonin availability depends upon blood $\mathrm{TrpH}$ levels ${ }^{3}$, which could modulate the psychoneural control of spontaneous alternation through presynaptic inhibition of hippocampal cholinergic terminals. Therefore, $\operatorname{TrpH}$ is a vital constituent of proteins and indispensable in human nutrition for establishing and maintaining a positive nitrogen balance ${ }^{2,4}$.

Vanadium concentrations correlated with the loss of $\mathrm{TrpH}$ residues in albumin ${ }^{5}$. Vanadium is an element which plays a variety of biochemical, pharmacological and physicochemical functions ${ }^{6,7}$. The interaction of vanadium with amino acids and proteins is a subject of current interest. In living systems, vanadium is an ultratrace element and is found both anionic and cationic forms, the most common ones being vanadate $\mathrm{H}_{2} \mathrm{VO}_{4}{ }^{-}$and oxovanadium(IV) $\left(\mathrm{VO}_{2}^{+}\right)^{8,9}$. It has been observed that simple inorganic vanadium compounds are more toxic than vanadium compounds with organic ligands and the efficacy of the metal based therapeutic agents changes drastically by making small changes in the organic ligands attached to the metal center ${ }^{10}$.

Vanadium complexes, particularly, vanadates and peroxovanadium compounds, have been implicated in many biological processes and therapeutic applications, as insulin-mimetics and antitumor agents ${ }^{11}$. The most important physiological effect of vanadium is the stimulation of glucose uptake and glucose metabolism ${ }^{12}$

A variety of vanadium complexes have been introduced as structural and / or functional models for biologically active vanadium compounds ${ }^{13}$. Schiff base complexes with an amino acid as the amine constituent constitute a specific subfamily within this group. From the medicinal point of view, it is desirable to design compounds which are water-soluble in order to facilitate uptake $^{14}$. In recent years, much interest has been focussed on oxo- and oxoperoxo complexes of vanadium with amino acid derivatives ${ }^{15}$. The complexes of vanadium are very interesting as model compounds to clarify several biochemical processes ${ }^{16-18}$. The interaction of vanadium with amino acids, peptides and proteins is a subject of current interes $\mathrm{t}^{19}$. There are few studies on the interaction between $\mathrm{V}(\mathrm{V}) / \mathrm{V}(\mathrm{IV})$ and amino acids $\mathrm{s}^{20-22}$. Extensive investigations on the interaction between vanadium and biologically relavant ligands such as glycine, L-histidine and its N-carboxymethyl derivative, alkoxides, or the dipeptides glycylglycine and glycyltyrosine both in solution and in the solid state have been made ${ }^{15}$. Although the complexes of V(III) with $\mathrm{TrpH}$, valin, phenylalanine and proline in the solid phase have been isolated from solution in nonaqueouse solvents ${ }^{23}$, no data are available on the complexes of vanadium(V) with $\mathrm{TrpH}$ in aqueous medium. In this paper, we report the synthesis, spectral characterization and electrochemistry of $\mathrm{Na}_{4}\left[\mathrm{~V}_{3} \mathrm{O}_{9}(\mathrm{Trp})\right]$ complex. Electrochemical study on the interaction of vanadium $(\mathrm{V})$ with $\mathrm{TrpH}$ is very important for the understanding of redox chemistry of vanadium and its drugs.

Scheme 1. The molecular structure of TrpH.<smiles>NC(Cc1c[nH]c2ccccc12)C(=O)O</smiles>

EXPERIMENTAL

\section{Reagents}

Tryptophan $(\mathrm{TrpH})$ and $\mathrm{NH}_{4} \mathrm{VO}$, were purchased from Merck and applied without further purification. In the voltammetric experiments, Britton Robinson (B-R) buffer (pH 6) was used as supporting electrolyte. All solution were prepared daily in ultrapure triply distilled water.

Synthesis

The complex was prepared by adding a hot $\mathrm{H}_{2} \mathrm{O}$ solution of $\mathrm{NH}_{4} \mathrm{VO}_{3}$ $\left(0.5 \times 10^{-3} \mathrm{M}\right)$ to a $\mathrm{NaOH}$ solution which is including the $\operatorname{TrpH}\left(1.0 \times 10^{-3} \mathrm{M}\right)$ and then $\mathrm{pH}$ of mixture was adjusted to 6 with dilute $\mathrm{HCl}$ and the light yelloworange coloured solution was kept at room temperature $\left(25^{\circ} \mathrm{C}\right)$. After a few weeks, brown precipitated was filtered off from the solution and washed with ethanol and dried in air. Elemental analyses for $\mathrm{C}, \mathrm{H}, \mathrm{N}$ and $\mathrm{S}$ were performed using a LECO CHNS 932 -Rapid analyzer at TÜBİTAK Laboratories of Ankara Research Center. Anal. Calc. for $\mathrm{Na}_{4}\left[\mathrm{~V}_{3} \mathrm{O}_{9}\right.$ (Trp) $](592.01 \mathrm{~g} / \mathrm{mol}) \% \mathrm{C}, 22.30 ; \%$ $\mathrm{H}, 1.86 ; \% \mathrm{~N}, 4.73$. Found: $\% \mathrm{C}, 22.68 ; \% \mathrm{H}, 1.71 ; \% \mathrm{~N}, 4.81$. According to the magnetic susceptibility measurements, the compound has diamagnetic nature. This result provides confirmatory evident for the presence of vanadium(V) in the structure.

\section{Spectroscopy}

The FT-IR spectra in the 4000-400 $\mathrm{cm}^{-1}$ regional were recorded from $\mathrm{KBr}$ pellets with a Jasco FT-IR 350 spectrometer at a resolution at $4 \mathrm{~cm}^{-1}$ based on averaging 32 sample and 16 background scans. ESR spectrum was collected using a Varian EC 109 spectrophotometre, the field being calibrated with diphenylpicrylhdrazyl (DPPH). The electronic absorption spectra in the 400$200 \mathrm{~nm}$ range were recorded on Unicam V2-100 UV/Vis spectrophotometer using $1 \mathrm{~cm}$ quartz cells. ${ }^{1} \mathrm{H}$ NMR spectra was measured in $\mathrm{D}_{2} \mathrm{O}$ solutions using tetramethylsilane (TMS) as internal standard and recorded on a BRUKER AVANCE DPX-400 spectrometer. LCMS-ESI analysis was obtained on the AGILENT 1100 MSD spectrometer at TÜBITAK Laboratories of Ankara Research Center. 


\section{Voltammetric measurements}

The voltammetric measurements were carried out using a EG\&G PAR Model 394B polarographic analyzer connected to an EG\&G PARC Model 303A polarographic stand (Princeton, NJ, USA). A hanging mercury drop electrode (HMDE; as working electrode), an $\mathrm{Ag} / \mathrm{AgCl} / \mathrm{KClsat}$. reference electrode and a Pt wire (as counter electrode) were used. The voltammetric measurements were carried out in B-R buffer as supporting electrolyte. Prior to each experiment, a voltammogram of the solution containing only supporting electrolyte was measured. Solutions of $\mathrm{NH}_{4} \mathrm{VO}_{3}$ and $\mathrm{TrpH}$ and the $\mathrm{Na}_{4}\left[\mathrm{~V}_{3} \mathrm{O}_{9}(\mathrm{Trp})\right]$ complex in water were separately added to the cell containing the supporting electrolyte and their voltammograms were recorded. Then, the additions of TrpH to the cell containing $\mathrm{NH}_{4} \mathrm{VO}_{3}$ were carried out and the voltammograms were recorded. Solutions were deaerated for about $8 \mathrm{~min}$ with pure nitrogen gas before starting the electrochemical experiments. Each measurement was performed with a fresh mercury drop at room temperature.

\section{RESULTS AND DISCUSSION}

\section{Spectral characterization of the complex}

\section{FT - IR spectra}

The infrared spectrum of the $\mathrm{Na}_{4}\left[\mathrm{~V}_{3} \mathrm{O}_{9}\right.$ (Trp)] complex has shown changes in the position and profiles of some bands as compared to those of the free TrpH (Fig. 1), suggesting participation of the groups that produce these bands in the coordination with vanadium atoms. Major changes are related to the carboxylate and amine bands. Also, new bands should also appear in the $300-497 \mathrm{~cm}^{-1}$ region in the spectra of vanadium complexes. These bands can be assigned to $v(\mathrm{~V}-\mathrm{O})$ and $v(\mathrm{~V}-\mathrm{N})$ coupled $^{24}$. The infrared spectrum of the $\mathrm{Na}_{4}\left[\mathrm{~V}_{3} \mathrm{O}_{9}(\mathrm{Trp})\right]$ complex exhibits $v(\mathrm{~V}-\mathrm{O})$ and $v(\mathrm{~V}-\mathrm{N})$ stretching bands at $495 \mathrm{~cm}^{-1}$ and $420 \mathrm{~cm}^{-1}$, respectively (Fig. 1). These bands can be attributed to binding via the carboxylate and amino nitrogen of Trp- in the complex. The presence of aromatic groups in the complex is supported by the appearance of bands in the $2900-3150 \mathrm{~cm}^{-1}$ region. Also, the infrared spectrum of complex exhibits a sharp band at $3415 \mathrm{~cm}^{-1}$, due to indole $v(\mathrm{NH})$ stretching vibrations of Trp ion $^{25}$. The free TrpH shows two bands in the $1610-1660 \mathrm{~cm}^{-1}$ and $1395-1430 \mathrm{~cm}^{-1}$ regions, corresponding to the asymmetric and symmetric $v\left(\mathrm{COO}^{-}\right)$stretching vibrations, respectivel ${ }^{26}$. These bands are shifted to higher wavenumbers (1615-1678 $\left.\mathrm{cm}^{-1}\right)$ and to lower wavenumbers (1356-1410 $\mathrm{cm}^{-1}$ ), respectively, after complexation with vanadium atoms, thus indicating coordination trough that group. The FT-IR bands at 945, 860, 835, 660 and $530 \mathrm{~cm}^{-1}$ are characteristics of cyclic vanadates ${ }^{27}$. In the addition, the terminal $v(\mathrm{~V}=\mathrm{O})$ and $v(\mathrm{~V}-\mathrm{O}-\mathrm{V})$ stretching frequencies in the complex appear as strong bands at 970 and $830 \mathrm{~cm}^{-1}$ and as a weak band at $650 \mathrm{~cm}^{-1}$, respectively ${ }^{28}$. The $v(\mathrm{C}-\mathrm{H})$ out of-plane deformations, characteristic of benzene ring of tryptophan is at $750 \mathrm{~cm}^{-1}$ for this complex (Fig. 1).
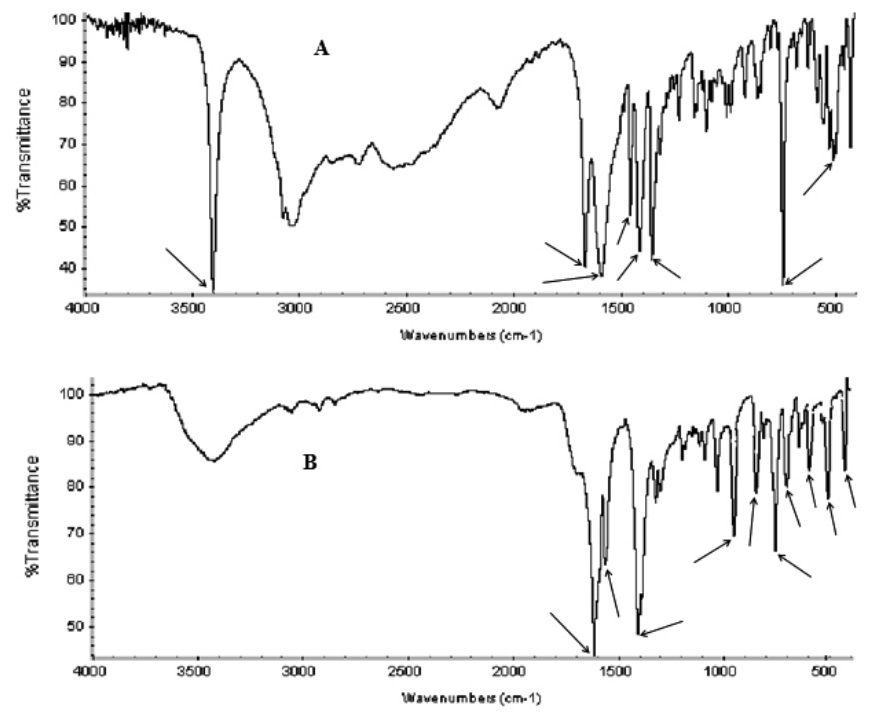

Fig. 1. FT-IR spectra of $\operatorname{TrpH}(\mathbf{A})$ and $\mathrm{Na}_{4}\left[\mathrm{~V}_{3} \mathrm{O}_{9}(\mathrm{Trp})\right]$ complex (B) in $\mathrm{KBr}$ disc. The arrows show the main peaks.
Esr

A freshly prepared aqueous solution of $\mathrm{Na}_{4}\left[\mathrm{~V}_{3} \mathrm{O}_{9}(\mathrm{Trp})\right]$ complex gave no ESR signal, since the present complex contains vanadium atom in the +5 oxidation state.

\section{UV-Vis spectra}

The UV-Vis spectra of $\mathrm{NH}_{4} \mathrm{VO}_{3}, \mathrm{TrpH}$ and the mixture of $\mathrm{NH}_{4} \mathrm{VO}_{3}$ with $\mathrm{TrpH}$ were recorded in the $200-400 \mathrm{~nm}$ in water (Fig. 2). The maximum absorption bands were given in Table 1. The electronic spectra of $\operatorname{TrpH}$ and $\mathrm{NH}_{4} \mathrm{VO}_{3}$ gave two $(219,280 \mathrm{~nm})$ and one $(266 \mathrm{~nm})$ the maximum absorption bands, respectively (Table 1). After the addition of TrpH to $\mathrm{NH}_{4} \mathrm{VO}_{3}$ solution, some shifts in the band positions and new bands were observed (Fig. 2 and Table 1). On the other hand, in the electronic spectra of the mixture of $\mathrm{NH}_{4} \mathrm{VO}_{3}$ with $\operatorname{TrpH}$, it has been shown that the band at $219 \mathrm{~nm}$ of TrpH shifts to $212 \mathrm{~nm}$. On raising the $\mathrm{NH}_{4} \mathrm{VO}_{3}$ concentration, a distinct increase in the intensity of 212 $\mathrm{nm}$ band supports the assumption of binding to TrpH. The UV-vis spectrum of $\mathrm{Na}_{4}\left[\mathrm{~V}_{3} \mathrm{O}_{9}(\mathrm{Trp})\right]$ exhibits four absorption bands. The two bands at 212 and $261 \mathrm{~nm}$ correspond to LMCT transition of terminal and bridging oxygens to vanadium, respectively. The band at $247 \mathrm{~nm}$ can be assigned to intraligand transitions, probably superimposed with the $\mathrm{O} \rightarrow \mathrm{V}$ charge transfer involving the double bonded oxo group ${ }^{29,30}$. The solutions of many vanadate $(\mathrm{V})$ species and vanadium $(\mathrm{V})$ bound to oxygen donor ligands give a yellow color which is due to intense LCMT bands tailing from the UV region ${ }^{31}$. A broad band at 350 $\mathrm{nm}$ is assigned to $\pi \rightarrow \pi^{*}$ transitions of the carboxylate group and interaction between the vanadium $d$ orbital and $\pi$ system of ligand.

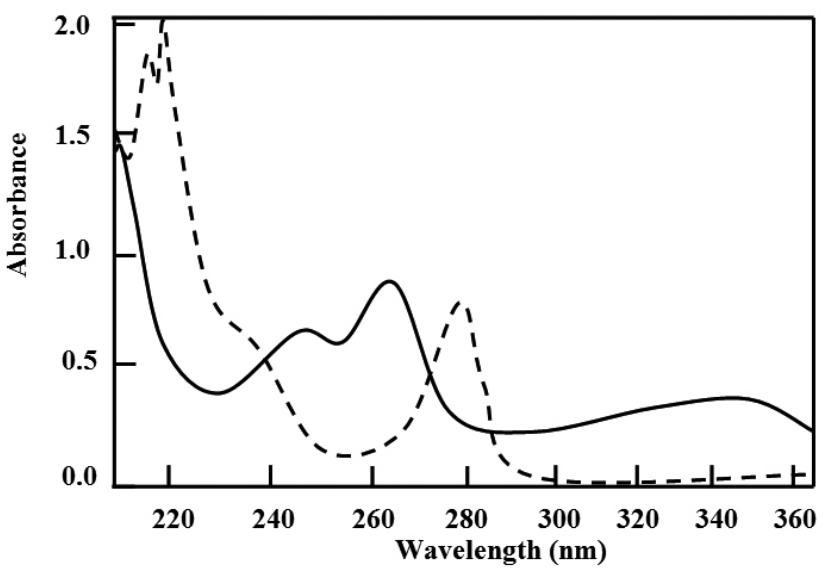

Fig. 2. Electronic spectra (in 200-380 nm region) of $1 \times 10^{-3} \mathrm{M} \mathrm{TrpH}$ solution (-------) and $1 \times 10^{-3} \mathrm{M} \mathrm{Na}_{4}\left[\mathrm{~V}_{3} \mathrm{O}_{9}(\mathrm{Trp})\right]$ complex solution (-

Table 1. Characteristic absorption maxima $(\mathrm{nm})$ data of $\mathrm{NH}_{4} \mathrm{VO}_{3}, \mathrm{TrpH}$, and of $\mathrm{Na}_{4}\left[\mathrm{~V}_{3} \mathrm{O}_{9}(\mathrm{Trp})\right]$ complex in aqueous solution.

\begin{tabular}{|c|c|c|}
\hline $\begin{array}{c}\mathrm{NH}_{4} \mathrm{VO}_{3} \\
\left(1 \times 10^{-3} \mathrm{M}\right)\end{array}$ & $\begin{array}{c}\mathrm{TrpH} \\
\left(1 \times 10^{-3} \mathrm{M}\right)\end{array}$ & $\begin{array}{c}\mathrm{Na}_{4}\left[\mathrm{~V}_{3} \mathrm{O}_{9}(\mathrm{Trp})\right] \\
\left(1 \times 10^{-3} \mathrm{M}\right)\end{array}$ \\
\hline 266 & 219 & 212 \\
\hline & 280 & 247 \\
\hline & & 261 \\
\hline & & $350(\mathrm{br})$ \\
\hline
\end{tabular}

\section{Mass}

The sturucture of the complex was further corroborated using electron spray ionisation mass spectrometry (ESI-MS). ESI-MS spectrum of the complex (Fig. 3) shows peak at $m / z 592.8$ which can be attributed to $\left\{\mathrm{Na}_{4}\left[\mathrm{~V}_{3} \mathrm{O}_{9}(\mathrm{Trp})\right]\right.$ $+1 \mathrm{H}\}$. In addition, electron spray ionisation mass spectrometry (ESI-MS) measurements (Fig. 3) show, besides the parent peak at $\mathrm{m} / \mathrm{z} 592.8$, the peaks at $m / z 205$ and 227 , corresponding to the $[\mathrm{M}+\mathrm{H}]^{+}$and to the sodium adduct $[\mathrm{M}+\mathrm{Na}]^{+}$of Trp, respectively ${ }^{32}$. This complex structure was proposed based on the MS data of the Trp- ion of $m / z 203$. The fragment ion of $m / z$ 188.1, formed because of the loss of water was shown in the spectrum. The peak at $\mathrm{m} / \mathrm{z} 390.9$ can be attributed to $\left\{\mathrm{Na}_{4}\left[\mathrm{~V}_{3} \mathrm{O}_{9}\right]+2 \mathrm{H}\right\}$. In addition, ESI-MS spectrum (Fig. 
3) shows peaks at $m / z 261.4$ and 199 which may be attributed to $\mathrm{Na}_{2} \mathrm{H}_{2} \mathrm{~V}_{2} \mathrm{O}$ and $\left[\mathrm{V}_{2} \mathrm{O}_{6}\right]^{2-}$, respectively. Finally, the results provided by ESI-MS verified the formation of $\mathrm{Na}_{4}\left[\mathrm{~V}_{3} \mathrm{O}_{9}(\mathrm{Trp})\right]$ complex.

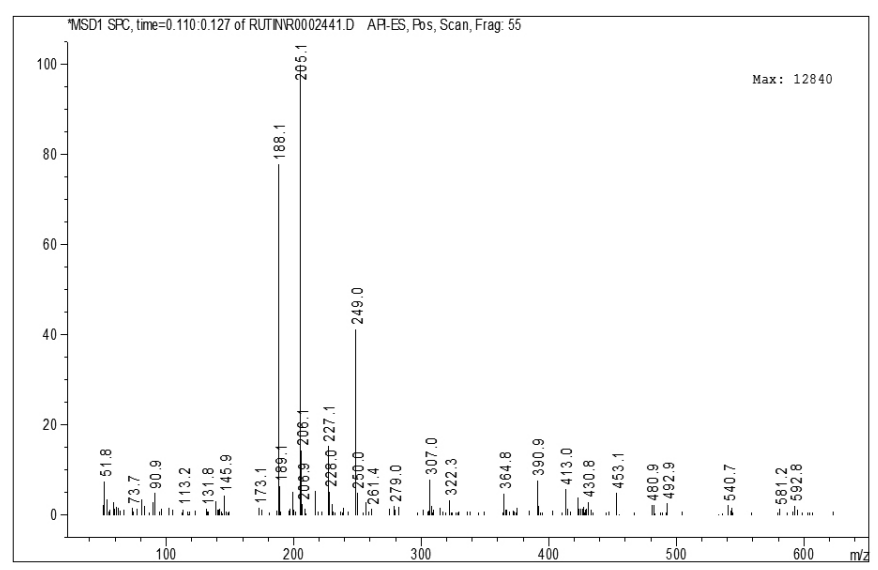

Fig. 3. Mass spectrum of $\mathrm{Na}_{4}\left[\mathrm{~V}_{3} \mathrm{O}_{9}(\mathrm{Trp})\right]$ complex.

Nmr

The ${ }^{1} \mathrm{H}$ NMR spectrum recorded from $\mathrm{D}_{2} \mathrm{O}$ solutions of TrpH was reported by Selvakannan et al. ${ }^{33}$. The peak at $3.4 \mathrm{ppm}$ (doublet) corresponds to the methilene protons and the peak at $4 \mathrm{ppm}$ corresponds to the $\alpha$-protons in the TrpH molecule ${ }^{33,34}$. Moreover, the multiplet peaks around 7-8 ppm represent the aromatic protons in the TrpH molecule ${ }^{33,34}$. By comparison with the ${ }^{1} \mathrm{H}$ NMR spectrum data of pure $\operatorname{TrpH}^{33}$, the ${ }^{1} \mathrm{H}$ NMR spectrum of the complex (Fig. 4) exhibits a slight up-field chemical shift of all protons. According to this observation, it can be said that the electronic environments of the $\mathrm{TrpH}$ protons change with the formation of the complex. At the complex, the negatively charged $\mathrm{V}_{3} \mathrm{O}_{0}{ }^{3-}$ ions affect the electronic environment of the $\mathrm{TrpH}$ protons, therefore shifting them slightly up-field ${ }^{33}$. The peaks at close to $3.95 \mathrm{ppm}$ correspond to protons coordinated to the $\alpha$-C of the primary amine (Fig. 4). This value is shifted relative to the solution value of pure $\operatorname{TrpH}(4.1 \mathrm{ppm})^{33}$ and indicates that binding of the $\mathrm{TrpH}$ molecule to the $\mathrm{V}_{3} \mathrm{O}_{9}{ }^{3-}$ ion occurs also via the primary amine groups in the amino acid.

The other important feature of the TrpH binding to $\mathrm{V}_{3} \mathrm{O}_{9}{ }^{3-}$ ion is that the resonances of the aromatic protons undergo shifts to high-field (Table 2). Consequently, the resonances observed in the ${ }^{1} \mathrm{H}$ NMR spectrum of the complex clearly demonstrate the existence of bound Trp- ligand in the complex.

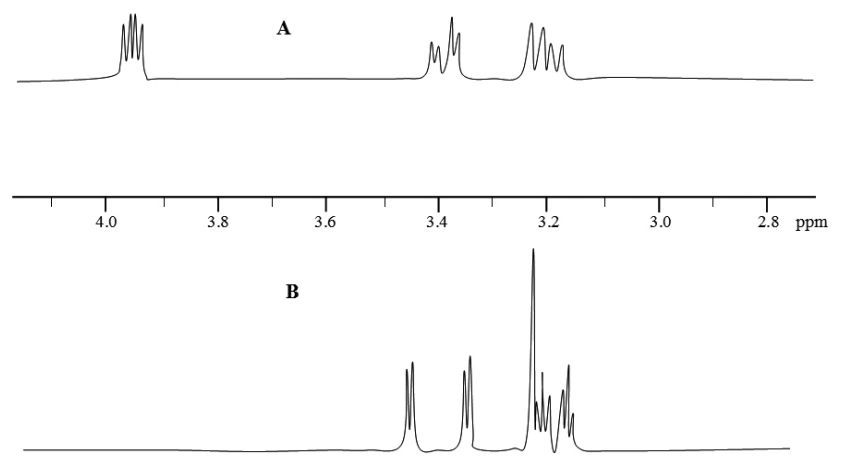

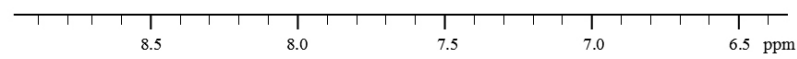

Fig. 4. The ${ }^{1} \mathrm{H}$ NMR spectra of $\mathrm{Na}_{4}\left[\mathrm{~V}_{3} \mathrm{O}_{9}(\right.$ Trp $\left.)\right]$ complex in $\mathrm{D}_{2} \mathrm{O}$. A) $\delta$ 2.7-4.2 p.p.m. region, B) $\delta 6.3-9.0$ p.p.m. region.

The voltammetric study on the interaction of $\mathrm{NH}_{4} \mathrm{VO}_{3}$ with $\mathrm{TrpH}$, and electrochemistry of the complex

$\mathrm{CV}$ was used to compare the electrochemical behaviors of the vanadium precursor $\left(\mathrm{NH}_{4} \mathrm{VO}_{3}\right)$, TrpH and the complex. The cyclic voltammogram of
TrpH solution in the absence of $\mathrm{NH}_{4} \mathrm{VO}_{3}$ produces a cathodic reduction peak $\left(E_{\mathrm{p}}=-1.32 \mathrm{~V}\right)$ in the Britton-Robinson buffer (pH 6.0) (Fig. 5). As can be seen in Fig. 5, the reduction process at $-1.32 \mathrm{~V}$ is irreversible. Because, there is no anodic counterpart is not. The peak at $-1.32 \mathrm{~V}$ could be due to a catalytic hydrogen reduction ${ }^{36}$.

Table 2. The chemical shifts (A $\delta$ ), p.p.m., of aromatic indole ring proton resonances of $\mathrm{L}-\mathrm{TrpH}$ at the free and bound forms.

\begin{tabular}{|c|c|c|}
\hline \multirow{2}{*}{ Proton } & \multicolumn{2}{|c|}{ L-TrpH } \\
\cline { 2 - 3 } & (bound) & (free) $^{35}$ \\
\hline H2 & 7.20 & 7.33 \\
\hline H4 & 7.65 & 7.73 \\
\hline H5 & 7.10 & 7.21 \\
\hline H6 & 7.15 & 7.29 \\
\hline H7 & 7.45 & 7.55 \\
\hline
\end{tabular}

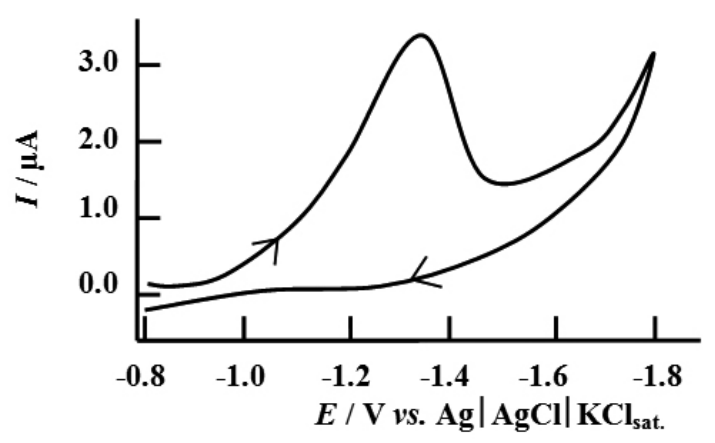

Fig. 5. The cyclic voltammogram of $1 \times 10^{-5} \mathrm{M}$ TrpH solution (in B-R buffer $\mathrm{pH}$ 6.0). 1U, the catalytic hydrogen wave of TrpH. Experimental conditions: scan rate, $200 \mathrm{mVs}^{-1}$; equilibrium time, $5 \mathrm{~s}$; drop size, medium.

Under the same conditions, cyclic voltammogram of $\mathrm{NH}_{4} \mathrm{VO}_{3}$ in the absence of TrpH gives a quasi-reversible peak couple with $E_{0} / E_{\text {values }}$ at $-0.16 \mathrm{~V} /-0.08 \mathrm{~V}$ and irreversible a reduction peak at $-0.48 \mathrm{~V}$ (Fig. 6 ). Usually two reduction steps are mentioned which are assigned from free $\mathrm{V}(\mathrm{V})$ to $\mathrm{V}(\mathrm{IV})$ and V(IV) to V(III) as follows ${ }^{37}$ :

$$
\begin{aligned}
& \mathrm{VO}_{3}^{-}+4 \mathrm{H}_{3} \mathrm{O}^{+}+\mathrm{e}^{-} \rightleftarrows \mathrm{VO}^{2+}+6 \mathrm{H}_{2} \mathrm{O} \quad \text { (Fig. 6, 1U) } \\
& \mathrm{VO}^{2+}+2 \mathrm{H}_{3} \mathrm{O}^{+}+\mathrm{e}^{-} \longrightarrow \mathrm{V}^{3+}+3 \mathrm{H}_{2} \mathrm{O} \quad \text { (Fig. 6, 2U) }
\end{aligned}
$$

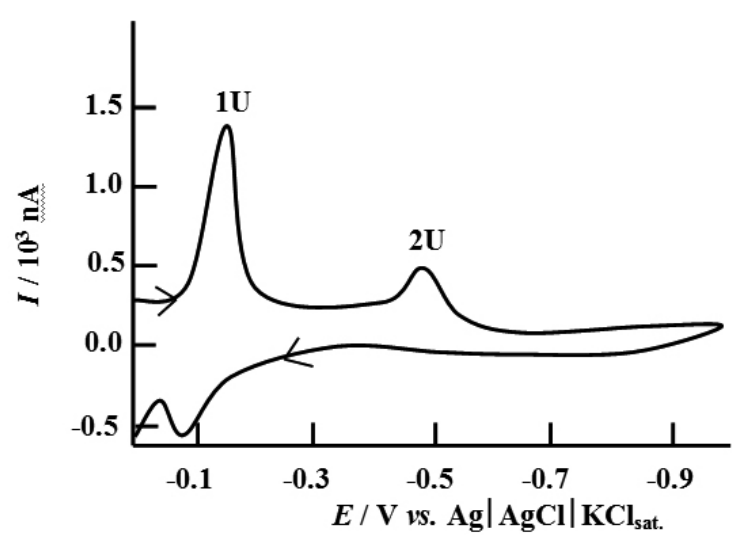

Fig. 6. Cyclic voltammogram of $5.5 \times 10^{-5} \mathrm{M} \mathrm{NH}_{4} \mathrm{VO}_{3}$ in the absence of $\mathrm{TrpH}$ (at B-R buffer pH 6.0). 1U, the reduction of free $\mathrm{V}(\mathrm{V})$ to $\mathrm{V}(\mathrm{IV}) ; \mathbf{2} \mathbf{U}$, the reduction of V(IV) to V(III). Experimental conditions are described as Fig. 5.

A dramatically change at the voltammetric behaviour of the $\mathrm{NH}_{4} \mathrm{VO}_{3}$ in the presence of $\mathrm{TrpH}$ is observed. With adding of $\mathrm{TrpH}$ into the cell containing $1 \times 10^{-5} \mathrm{M} \mathrm{NH}_{4} \mathrm{VO}_{3}$, two new cathodic reduction peaks are observed at $-0.38 \mathrm{~V}$ 
and $-1.01 \mathrm{~V}$ (Fig. 7), while the peak currents of free $\mathrm{NH}_{4} \mathrm{VO}_{3}$ decrease (data not shown here). The potential of this new peak $(-0.38 \mathrm{~V})$ is different from that of free $\mathrm{V}(\mathrm{V})$. The reversible cathodic reduction peak at $-0.38 \mathrm{~V}$ may be due to the reduction of $\mathrm{V}(\mathrm{V})$ ions complexed with tryptophanate (Trp-) in the aqueous media. Under the same experimental conditions, similar results have been also obtained by the aqueous solution of the solid $\mathrm{Na}_{4}\left[\mathrm{~V}_{3} \mathrm{O}_{9}(\operatorname{Trp})\right]$ complex. As can be seen in Fig. 8, the cyclic voltammogram of dissolved $\mathrm{Na}_{4}\left[\mathrm{~V}_{3} \mathrm{O}_{9}(\mathrm{Trp})\right]$ complex shows two new peaks at $-0.39 \mathrm{~V}$ (reversible) and $-1.06 \mathrm{~V}$ (irreversible). As a result, the voltammetric measurements show that there is an interaction between vanadium $(\mathrm{V})$ and $\mathrm{TrpH}$ in aqueous solution. Moreover, the redox potentials of $\mathrm{NH}_{4} \mathrm{VO}_{3}$ and $\mathrm{TrpH}$ mixture are agree with those of the dissolved $\mathrm{Na}_{4}\left[\mathrm{~V}_{3} \mathrm{O}_{9}(\mathrm{Trp})\right]$ complex in water.

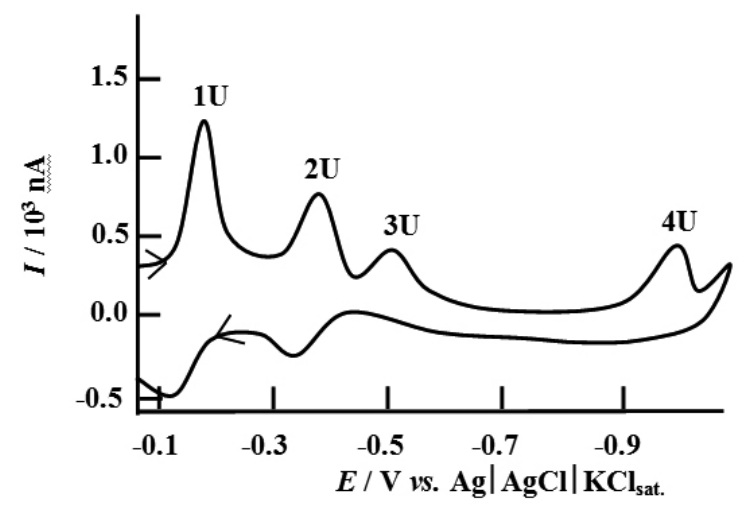

Fig. 7. Cyclic voltammogram of $1 \times 10^{-5} \mathrm{M} \mathrm{NH}_{4} \mathrm{VO}_{3}$ solution in the presence ) and absence (------) of $1 \times 10^{-5} \mathrm{M} \mathrm{TrpH}$ (at B-R buffer $\mathrm{pH}$ 6.0). 1U, the reduction of free $\mathrm{V}(\mathrm{V})$ to $\mathrm{V}(\mathrm{IV}) ; \mathbf{2} \mathbf{U}$, the reduction of the complex formed between $\mathrm{NH}_{4} \mathrm{VO}_{3}$ and $\mathrm{TrpH}$ at $\mathrm{pH} 6.0 ; \mathbf{3} \mathbf{U}$, the reduction of $\mathrm{V}(\mathrm{IV})$ to $\mathrm{V}(\mathrm{III})$; $\mathbf{4 U}$, the catalytic hydrogen wave of the complex. Experimental conditions are described as Fig. 5.

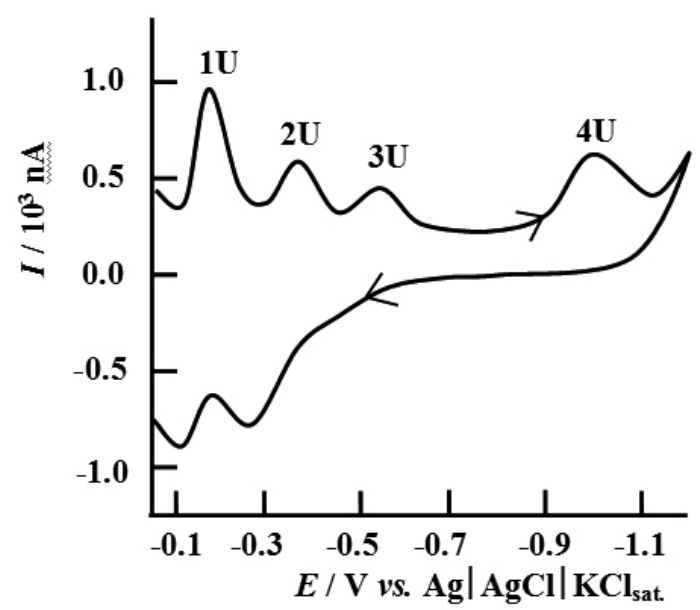

Fig. 8. Cyclic voltammogram of $\mathrm{Na}_{4}\left[\mathrm{~V}_{3} \mathrm{O}_{9}(\mathrm{Trp})\right]$ complex dissolved in water (at B-R buffer $\mathrm{pH}$ 6.0). $\mathbf{1} \mathbf{U}$, the reduction of free $\mathrm{V}(\mathrm{V})$ to $\mathrm{V}(\mathrm{IV})$; $\mathbf{2} \mathbf{U}$, the reduction of $\mathrm{Na}_{4}\left[\mathrm{~V}_{3} \mathrm{O}_{9}\right.$ (Trp)] complex; $\mathbf{3} \mathrm{U}$, the reduction of $\mathrm{V}(\mathrm{IV})$ to $\mathrm{V}(\mathrm{III})$; $4 \mathbf{U}$, the catalytic hydrogen wave of $\mathrm{Na}_{4}\left[\mathrm{~V}_{3} \mathrm{O}_{9}(\mathrm{Trp})\right]$ complex. Experimental conditions are described as Fig. 5.

\section{CONCLUSION}

$\mathrm{Na}_{4}\left[\mathrm{~V}_{3} \mathrm{O}_{9}(\mathrm{Trp})\right]$ complex was firstly prepared by the reaction between $\mathrm{NH}_{4} \mathrm{VO}_{3}$ and $\mathrm{TrpH}$ in aqueous solution. Structural features of this complex were obtained from its elemental analyses, magnetic susceptibility, mass, FT-IR, UV-Vis, ${ }^{1} \mathrm{H}-\mathrm{NMR}$ and ESR spectral studies. The electrochemistry of the complex has been studied using cyclic voltammetry. From the ESR and the magnetic susceptibility measurements, it is evident that the complex is diamagnetic. The characteristic frequencies of cyclic vanadates are shown in the FT-IR spectrum of $\mathrm{Na}_{4}\left[\mathrm{~V}_{3} \mathrm{O}_{9}(\mathrm{Trp})\right]$ complex. Also, the complex displays two new peaks at $-0.39 \mathrm{~V}$ (reversible) and $-1.06 \mathrm{~V}$ (irreversible) in comparison to the cyclic voltammogram of $\mathrm{NH}_{4} \mathrm{VO}_{3}$.

\section{ACKNOWLEDGEMENT}

Authors thank to The Scientific and Technological Research Council of Turkey (TÜBİTAK) for financial support throughout this study by project of $105 \mathrm{~T} 245$.

\section{REFERENCES}

1. A. Carlsson, M. Lindqvist. N.S. Arch. Pharmacol. 303, 157, (1978).

2. G.-P. Jin, X.-Q. Lin, Electrochem. Commun. 6, 454, (2004).

3. I. González-Burgos, E. Olvera-Cortés, A. R. Del Angel-Meza, A. FeriaVelasco, Neurosci. Lett. 190, 143, (1995).

4. Y. Ya, D. Luo, G. Zhan, C. Li, Bull. Korean Chem. Soc. 29, 928, (2008)

5. G.J. Quinlan, C. Coudray, A. Hubbard, J.M.C. Gutteridge, J. Pharm. Sci. 81, 611, (1992).

6. M. Weyand, H.-J. Hecht, M. Kieß, M.-F. Liaud, H. Vilter, D. Schomburg, J. Mol. Biol. 293, 595, (1999).

7. A. Butler, J.V. Walker, Chem. Rev. 93, 1937, (1993).

8. M. Garner, J. Reglinski, W.E. Smith, J. McMurray, I. Abdullah, R. Wilson, J. Biol. Inorg. Chem. 2, 235, (1997).

9. D. Rehder, BioMetals 5, 3, (1992).

10. B.K. Keppler, C. Friesen, H.G. Moritz, H. Vongerichten, E. Vogel, Struct. Bonding 78, 97, (1991).

11. D.C. Crans, A.S. Tracey, In Vanadium Compounds: Chemistry, Biochemistry, and Therapeutic Applications; A.S. Tracey, D.C. Crans (Eds.); American Chemical Society: Washington, DC, 1998; Vol.711, pp $2-29$.

12. A.K. Saxena, P. Srivastava, R.K. Kale, N.Z. Baquer, Biochem. Pharmacol. 45, 539, (1993)

13. D. Rehder, S. Jantzen, in: J.O. Nriagu (Ed.), Vanadium in the environment, Wiley, New York, 1998, Ch. 11.

14. C. Griining, H. Schmidt, D. Rehder, Inorg. Chem. Commun. 2, 57, (1999).

15. M. Casny, M. Sivak, D. Rehder, Inorg. Chim. Acta 355, 223, (2003).

16. D. Rehder, Angew. Chem., Int. Ed. Engl. 30, 148, (1991).

17. S. Çakır, E. Biçer, Bioelectrochemistry 64, 1, (2004).

18. P. Magill, C. Floriani, A. Chiesi-Villa, C. Rizzoli, Inorg. Chem. 32, 2729, (1993).

19. K. Bukietyńska, H. Podsiadły, Z. Karwecka, J. Inorg. Biochem. 94, 317, (2003).

20. E.J. Baran, J. Inorg. Biochem. 80, 1, (2000).

21. J.C. Pessoa, I. Tomaz, T. Kiss, P. Buglyo, J. Inorg. Chem. 84, 259, (2001).

22. J.C. Pessoa, T. Gajda, R.D. Gillard, T. Kiss, S.M. Luz, J.J.G. Moura, I Tomaz, J.P. Telo, I. Torok, J. Chem. Soc., Dalton Trans. 3587, (1998).

23. N.D. Chasteen, Ed., Vanadium in Biological Systems, Dordrecht, The Netherlands, Kluwer Academic Publishers, 1990.

24. S. Liu, S. Gao, Inorg. Chim. Acta 282, 149, (1998).

25. F. Athar, F. Arjmand, S. Tabassum, Transit. Met. Chem. 26, 574, (2001).

26. S.S. Sandhu, J.S. Jaswal, Indian J. Chem. 29A, 245, (1990).

27. P. Roman, A.S. Jose, A. Luque, J. M. Gutierrez-Zorrilla, Inorg. Chem. 32, $775,(1993)$

28. J.C. Pessoa, I. Cavaco, I. Correia, M.T. Duarte, R.D. Gillard, R.T. Henriques, F.J. Higes, C. Madeira, I. Tomaz, Inog. Chim. Acta 2, 1, (1999).

29. A.H. Jubert, A.C. Gonzalez-Baro, R. Pis-Diez, E.J. Baran, J. Raman Spectrosc. 23, 273, (1992).

30. A.C. Gonzalez-Baro, O.E. Piro, B.S. Parajon-Costa, E.J. Baran, E.E. Castellano, Monatsh. Chem. 129, 31, (1998).

31. C.D. Garner, D. Collison, F.E. Mabbs, In: H. Sigel, A. Sigel (Eds), Metal ions in biological systems, Vol 31: Vanadium and its role in life, Marcel Dekker, New York, 1995, Ch. 19, p. 635.

32. M.R.M. Domingues, P. Domingues, A. Reis, C. Fonseca, F.M.L. Amado, A.J.V. Ferrer-Correia, J. Am. Soc. Mass Spectrom. 14, 406, (2003).

33. P.R. Selvakannan, S. Mandal, S. Phadtare, A. Gole, R. Pasricha, S.D. Adyanthaya, M. Sastry, J. Colloid Interf. Sci. 269, 97, (2004).

34. M.-C. Corbeil, A.L. Beauchamp, Can. J. Chem. 66, 2458, (1988).

35. V. Ramesh, T. Brown, Biochem. J. 315, 895, (1996).

36. S.Çakır, E. Biçer, A. Eleman, Transit. Met. Chem. 26, 89, (2001).

37. S. Sander, G. Henze, Fresenius J. Anal. Chem. 356, 259, (1996). 